\title{
Development of a Dynamic Modelling Tool for Agricultural Production Projections in Relation to GHG Mitigation Measures
}

\author{
Peteris Rivza, Ivars Mozga, Laima Berzina \\ Latvia University of Agriculture
}

\begin{abstract}
The present research study outlines a methodology for assessing agricultural production forecasts in Latvia with regard to the outcome of GHG emissions. A dynamic model was developed, which allows assessment of effects of various decisions and measures on agricultural production. The model consists of several mutually connected blocks: 1) modelling of agricultural indicators with relation to macroeconomic indicators; 2) calculation of GHG emissions according to Intergovernmental Panel on Climate Change (IPCC) guidelines; 3) scenarios for analysing the impact on emissions by various mitigation measures, and 4) results for summarising the modelling outcome. The developed model may be used as a decision support tool for impact assessment of various measures to reduce emissions and for seeking solutions to GHG emission mitigation by agricultural policy decisions. The model was developed using the Powersim Studio software.
\end{abstract}

Keywords: GHG emissions, dynamic model, agriculture.

\section{INTRODUCTION}

After regaining its independence, a number of significant processes took place in Latvia, which influenced its agriculture: the collapse of collective farming caused a sharp decrease in the output of the livestock and crop industries (Figure 1) and Latvia's accession to the EU in 2004 contributed to the restructuring of its agriculture and the beginning of its development. The value of crop and livestock products produced by the crop and livestock subindustries mainly determines the nature of and the trend in the development of the agricultural industry (Figure 1).

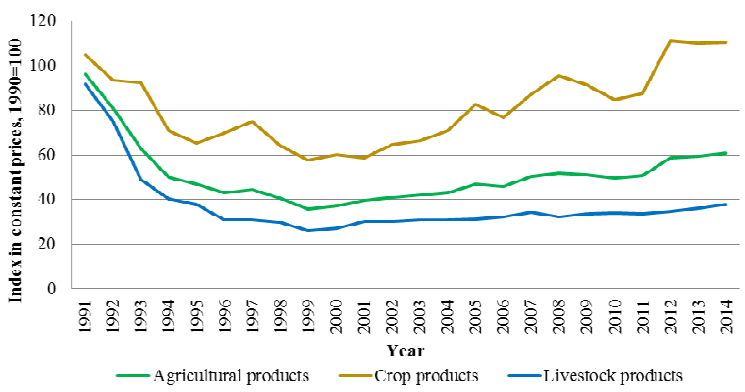

Fig.1. Changes of agricultural commodity price indexes in Latvia (constant prices) $(1990=100)$ from 1991 to 2014 [1].

An analysis of the changes in the agricultural commodity price indexes (Figure 1) reveals that agricultural output constantly increased, particularly in crop farming. Although the crop sector grew dynamically, it still has considerable development potential because the total cropped area in 2014 accounted for only $70.7 \%$ of that in 1990 .
The strong trends in agricultural development observed in Latvia will remain in future too; therefore, the system of long-term forecasting of agricultural indicators and of GHG emission modelling for the agricultural sector has to be improved. The Dynamic Model for the Long-term Forecasting of Agricultural Indicators and GHG Emission Reduction described in the paper provides such a possibility.

\section{MATERIALS AND METHODS}

The dynamic optimisation model for the longterm forecasting of agricultural indicators and GHG emission reduction consists of several large modules:

- Macroeconomic data module;

- Livestock indicator module;

- Crop indicator module;

- Module for calculating GHG emissions for the agricultural sector;

- Module for generating $\mathrm{GHG}$ emission reduction scenarios for the agricultural sector;

- Optimisation module for selecting GHG emission reduction scenarios for the agricultural sector;

- Module for summarising the modelling outcome.

The structure of the dynamic model is presented as well as the interconnections of individual modules in Figure 2. http://dx.doi.org/ 10.17770/etr2017vol2.2588 


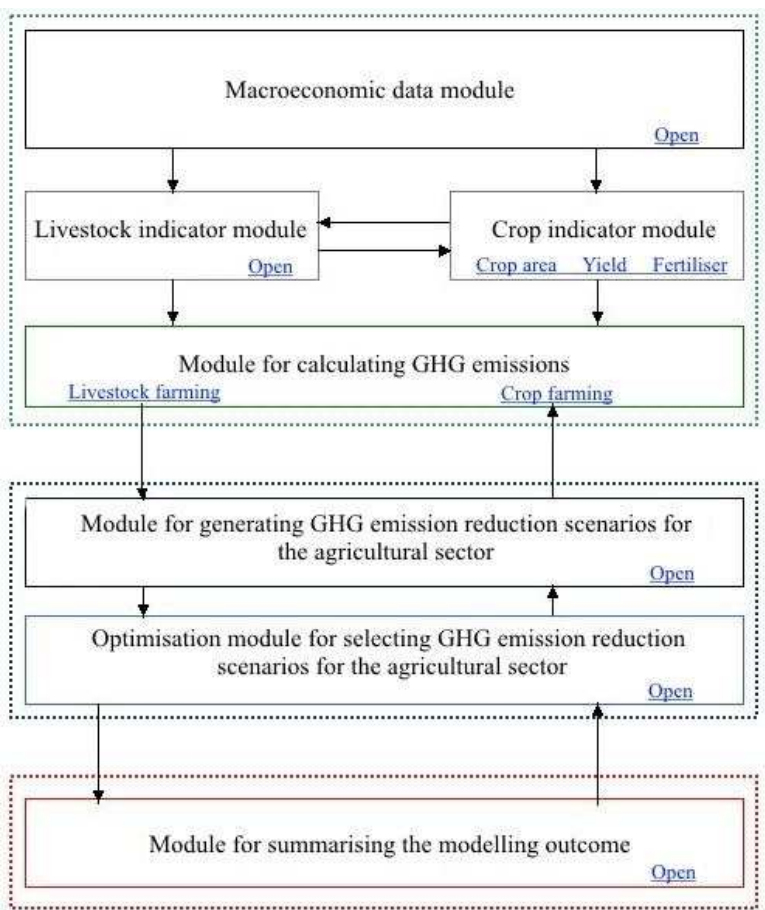

Fig.2. Structural scheme for the dynamic optimisation model for the long-term forecasting of agricultural indicators and reduction of GHG emission.

In the dynamic model, the long-term forecasting of agricultural indicators for Latvia is based on linear multifactor regression equations [2], choosing the following macroeconomic indicators as independent factors [3; 4]: GDP, share of agriculture in GDP, population and prices of agricultural commodities [5].

The generalised logistic function or Richards' curve were employed in forecasting some agricultural indicators that in the future might tend to near a level set by experts (areas cropped with wheat, maize, rapeseed and potato; numbers of fur animals and horses) [6].

The key sources of agricultural GHG emissions or active data are modelled in the modules of livestock and crop indicators. The emissions produced by the sources are estimated in the module for calculating GHG emissions. The amount of GHG emissions from livestock is determined by multiplying the simulated number of agricultural animals by the emission factor according to 2006 IPCC Guidelines for National Greenhouse Gas Inventories [7].

Methane emissions from dairy cows and cattle are calculated employing the emission factors determined according to the Tier 2 methodology, which are adjusted to the expected milk yields of dairy cows, given the fact that one of the most important variables related to methane emissions is livestock productivity. The default emission factors set by the 2006 IPCC Guidelines (Tier1) [7] or the emission factors employed in other countries are used for the other agricultural animals (goats, sheep, horses, pigs, poultry, rabbits and fur animals).
Methane emissions from fermentation in the gastrointestinal tract for every category of livestock are calculated by the following formula [7]:

$$
\mathrm{CH}_{4} \text { EntericFermentation }=E F_{(T)} \cdot \frac{N_{(T)}}{10^{6}}
$$

where $\mathrm{CH}_{4}$ Enteric Fermentation - methane emissions from enteric fermentation, $\mathrm{kt} \mathrm{CH}_{4}$ year $^{-1}$;

$E F_{(T)}$ - emission factor for the defined livestock population, $\mathrm{kg} \mathrm{CH}_{4}$ head $^{-1}$ year $^{-1}$;

$N_{(T)}$ - the number of heads for livestock species / category $\mathrm{T}$ in the country;

$T-$ species/category of livestock.

However, the Tier 2 approach suggests calculating the emission factor by the following equation:

$$
E F=\left[\frac{G E \cdot\left(\frac{Y_{m}}{100}\right) \cdot 365}{55.65}\right]
$$

where $E F$ - emission factor, $\mathrm{kg} \mathrm{CH}_{4}$ head $^{-1}$ year-1; $G E$ - gross energy intake, MJ head ${ }^{-1}$ year $^{-1}$; $Y_{m}$ - methane conversion factor, per cent of gross energy in feed converted to methane; 55.65 - factor of energy content of methane.

However, methane emissions from manure management are calculated by the following formula [7]:

$$
C H_{4} \text { Manure }=\sum_{(T)} \frac{\left(E F_{(T)} \cdot N_{(T)}\right)}{10^{6}}
$$

where $\mathrm{CH}_{4}$ Manure $=\mathrm{CH}_{4}$ emissions from manure

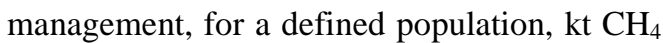
$\mathrm{yr}^{-1}$;

In addition to methane emissions from manure management, nitrous oxide $\mathrm{N}_{2} \mathrm{O}$ emissions are also calculated [7]:

$N_{2} N_{D(m m)}=\left[\sum_{S}\left[\sum_{T}\left(N_{(T)} \cdot N e x_{(T)} \cdot M S_{(T, S)}\right)\right] \cdot E F_{3(S)}\right] \cdot \frac{44}{28}$

where $\mathrm{N}_{2} \mathrm{O}_{D(\mathrm{~mm})}-$ direct $\mathrm{N}_{2} \mathrm{O}$ emissions from Manure Management in the country, $\mathrm{kg} \mathrm{N}_{2} \mathrm{O}$ year ${ }^{-1}$;

$\mathrm{Nex}_{(T)}$ - annual average $\mathrm{N}$ excretion per head of species/category $\mathrm{T}$ in the country, $\mathrm{kg} \mathrm{N}$ animal $^{-1} \mathrm{yr}^{-1}$;

$M S_{(T, S)}$ - fraction of total annual nitrogen excretion for each livestock species/category $\mathrm{T}$ that is managed in manure management system in the country, dimensionless;

$E F_{3(S)}$ - emission factor for direct $\mathrm{N}_{2} \mathrm{O}$ emissions from manure management system $\mathrm{S}$ in the country, $\mathrm{kg} \mathrm{N}_{2} \mathrm{O}-\mathrm{N} \mathrm{kg}^{-1} \mathrm{~N}$ in the manure management system;

$S$ - manure management system. 
The emissions from livestock calculated by the model are presented graphically as well (Figure 3).
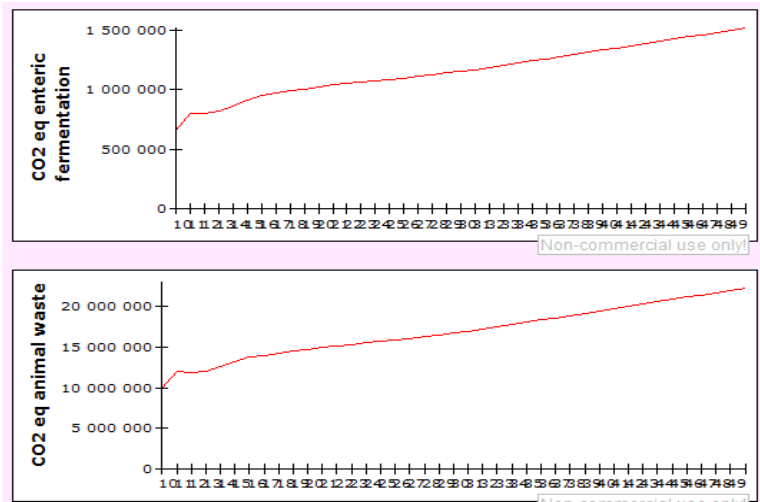

Fig.3. GHG emissions from livestock in the period from 2010 to 2050 .

Based on the expected cropped area and crop yields, the crop indicator module calculates the amount of nitrogen in crop residues, the nitrogen emission factor of which, according to the 2006 IPCC Guidelines [7], is equal to $0.01 \mathrm{~kg} \mathrm{~N}_{2} 0-\mathrm{N}(\mathrm{kg} \mathrm{N})^{-1}$. Nitrous oxide and carbon dioxide emissions due to fertilising and liming are determined according to the following emission factors set by the 2006 IPCC Guidelines [7]: $0.01 \mathrm{~kg} \mathrm{~N}_{2} 0-\mathrm{N}(\mathrm{kg} \mathrm{N})^{-1}$ for fertilisers and manure, $0.13 \mathrm{t} \mathrm{CO}_{2}-\mathrm{C}$ year- ${ }^{-1}$ for lime fertilisers and $0.2 \mathrm{t} \mathrm{CO}_{2}-\mathrm{C}$ year ${ }^{-1}$ for carbamide. A total amount of nitrous oxide emissions from crop farming, according to the IPCC guidelines, is calculated by the formula [7]:

$$
\mathrm{N}_{2} \mathrm{O}_{\text {Direct }}-\mathrm{N}=\mathrm{N}_{2} \mathrm{O}-\mathrm{N}_{\text {Ninputs }}
$$

where

$$
N_{2} O_{\text {Direct }}-N_{\text {inputs }}=\left(F_{S N}+F_{C R}\right) \cdot E F_{1}
$$

where $\mathrm{N}_{2} \mathrm{O}-\mathrm{N}$ - annual direct $\mathrm{N}_{2} \mathrm{O}-\mathrm{N}$ emissions produced from managed soils, $\mathrm{kg} \mathrm{N}_{2} \mathrm{O}-\mathrm{N} \mathrm{yr}^{-1}$; $\mathrm{N}_{2} \mathrm{O}-\mathrm{N}_{\mathrm{N}}$ inputs - annual direct $\mathrm{N}_{2} \mathrm{O}-\mathrm{N}$ emissions from $\mathrm{N}$ inputs to managed soils, $\mathrm{kg}$ $\mathrm{N}_{2} \mathrm{O}-\mathrm{N} \mathrm{yr}^{-1}$;

$F_{S N}$ - annual amount of synthetic fertiliser $\mathrm{N}$

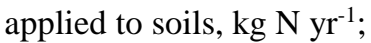

$F_{C R}$ - annual amount of $\mathrm{N}$ in crop residues (above-ground and below-ground), including $\mathrm{N}$-fixing crops, and from forage/pasture renewal, returned to soils, $\mathrm{kg} \mathrm{N} \mathrm{yr}^{-1}$;

$E F_{1}$ - emission factor for $\mathrm{N}_{2} \mathrm{O}$ emissions from $\mathrm{N}$ inputs, $\mathrm{kg} \mathrm{N}_{2} \mathrm{O}-\mathrm{N} \mathrm{kg}^{-1} \mathrm{~N}$ input.

Finally, the emissions calculation is converted into $\mathrm{CO}_{2}$ equivalent, acquiring a total emission equivalent.

The module for GHG emission reduction defines the following six GHG emission reduction scenarios:

1. Baseline scenario - 2015: the baseline scenario is usually chosen if development takes place in the future in line with the historical trends. The baseline scenario uses 2015 agricultural forecasts for the period up to 2050. The baseline scenario involves all the GHG emission reduction measures introduced and to be introduced in Latvia. The factors necessary for GHG emission calculations are available in the GHG emission calculation module.

2. Baseline scenario - 2015+: the baseline scenario with extra activities that involves an assessment of the impact of two GHG emission reduction measures defined according to the 2015 forecasts:

a. Measure Precise Crop Farming involves an assumption that the largest farms (sized 100 and more ha) that farm more than 50\% of the UAA in Latvia will introduce technologies that reduce the total consumption of nitrogen fertilisers by $5 \%$ as well as the loss of nitrogen due to leaching from $30 \%$ to $15 \%$ in the period from 2015 to 2050 ;

b. Measure Precise Livestock Farming involves an assumption that precise feed rations will gradually result in higher digestibility of feedstuffs - from 65 to $80 \%$ for dairy cows and from 65 to $70 \%$ for other cattle.

3. Agricultural intensification scenario: agricultural growth through the application of new technologies and innovations, observing the environmental and sustainable development principles.

4. Organic farming scenario: considerable increases in the production of organic food.

5. Bioenergy scenario: considerable increases in the production of bioenergy.

6. Integrated land management scenario: optimised agricultural land management, which involves afforestation, wetland and organic soil management and other issues.

After summarising the modelling outcomes for the GHG emission scenarios, proposals can be developed for the GHG emission reduction programme for the agricultural industry at national level.

\section{RESULTS AND DISCUSSION}

Given the fact that it is planned to intensify agricultural production and reintegrate unutilised agricultural lands into agricultural production in Latvia, an increase in GHG emissions from the agricultural sector can reach $34 \%$ in 2020 , compared with the level of 2005. In 2050, the amount of emissions could additionally increase by more than $70 \%$ (Figure 4). The main reason for the increase is the positive growth pace of agricultural production, which is based on the forecasts and an assumption that output in dairy, pig and poultry farming, grain 
farming and other agricultural industries will increase.

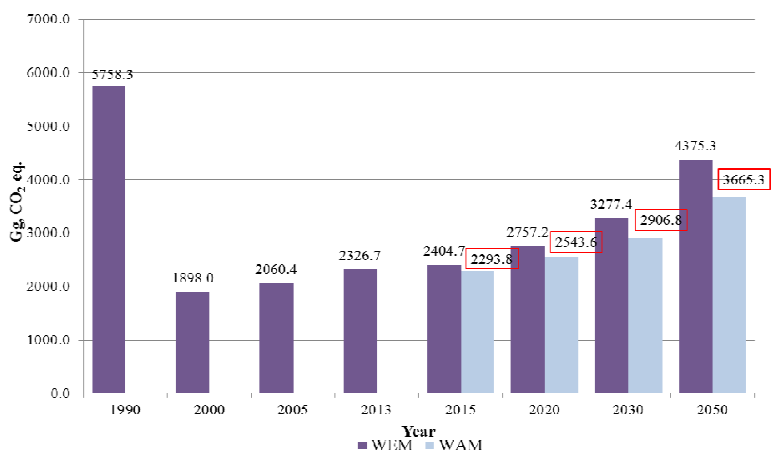

Fig. 4. Comparison of the agricultural GHG emission forecasts and the historical emissions (1990-2050).

The results of forecasting the agricultural GHG emissions are integrated in two scenarios. Scenario 1 (the baseline scenario 2015) with existing measures (WEM) includes the set emission reduction measures (Figure 4). Scenario 2 with additional measures (WAM) assesses the impact of additional measures to be introduced (the baseline scenario 2015+). The WAM scenario, which was designed in 2015, includes two extra measures: precise crop farming and precise livestock farming. It was estimated that the introduction of the extra measures would mainly reduce emissions from enteric fermentation and soil management.

If increasing the cropped area and the number of livestock, the emissions still tend to decrease compared with 1990. However, with agricultural production increasing, the total amount of GHG emissions from the agricultural sector will increase by $34 \%$ (by $23 \%$ with the extra measures) in 2020 and by up to $59 \%$ (by $41 \%$ with the extra measures) in 2030 (Figure 4).

\section{CONCLUSIONS}

1. With agricultural output increasing in Latvia, reducing GHG emissions from agriculture is a serious challenge for the country.
2. Based on macroeconomic forecasts for Latvia, the dynamic model allows forecasting agricultural indicators for a long term.

3. The dynamic model estimates GHG emissions according to the 2006 IPCC methodology.

4. The GHG emission reduction scenarios allow simulating various situations and find the most appropriate one for Latvia.

\section{REFERENCES}

[1.] Central Statistical Bureau of the Republic of Latvia. Agricultural Output Indices (at constant prices). CSB database. [online] [20.02.2016] Available at: http://data.csb.gov.lv/pxweb/lv/lauks/lauks_ikgad_01Lau ks_visp/LI0010.px/?rxid=cdcb978c-22b0-416a-aaccaa650d3e2ce0

[2.] Rivza P., Berzina L., Mozga I., Lauva D. Long-term Forecasting of Agricultural Indicators and GHG Emissions in Latvia. Proceedings of the 25th NJF Congress, Riga, 2015, pp. 281-288.

[3.] Informatīvais zinojums par darba tirgus vidēja un ilgtermina prognozēm. EM. (Informative Report on Labour Market Medium and Long-term Forecasts. Ministry of Economics), 2012, 88 p. (in Latvian) [online] [01.03.2016] Available at: https://www.em.gov.lv/files/tautsaimniecibas_attistiba/EMZ ino_150814.pdf .

[4.] Ozolina V., Pocs R. Macroeconomic Modelling and Elaboration of the Macro-Econometric Model for the Latvian Economy. Scientific Monograph. Riga, RTU Press, 2013, $191 \mathrm{p}$.

[5.] Fischer G. World Food and Agriculture to 2030/50: How do Climate Change and Bioenergy Alter the Long-term Outlook for Food, Agriculture and Resource Availability? Proceedings of an Expert Meeting on How to Feed the World in 2050. Food and Agriculture Organization of the United Nations Economic and Social Development Department, 2016. [online] [05.03.2016] Available at: http://www.fao.org/3/a-ak542e/ak542e07.pdflauk

[6.] Fekedulegn, D., Mac Siurtain, M.P., \& Colbert, J.J. (1999). Parameter Estimation of Nonlinear Growth Models in Forestry. Silva Fennica 33 (4): 32712.

[7.] 2006 IPCC Guidelines for National Greenhouse Gas Inventories, Volume 4, Agriculture, Forestry and Other Land Use, 2006. [online] [02.03.2016] Available at: http://www.ipcc-nggip.iges.or.jp/public/2006gl/vol4.html 